\title{
Meningkatkan Perkembangan Motorik melalui Senam Ritmik pada Siswa Kelas VI Sekolah Dasar
}

\author{
Basri \\ Sekolah Dasar Negeri 020-UPTD Pendidikan Samarinda Ilir
}

\begin{tabular}{l} 
INFO ARTIKEL \\
\hline Riwayat Artikel: \\
Diterima: $12-01-2019$ \\
Disetujui: $19-03-2019$ \\
\hline
\end{tabular}

\section{Kata kunci:}

motor development; rhythmic gymnastics; elementary school students; perkembangan motorik; senam ritmik; siswa sekolah dasar

\author{
Alamat Korespondensi: \\ Basri \\ Sekolah Dasar Negeri 020 \\ UPTD. Pendidikan Samarinda Ilir \\ E-mail: ayikgugun@gmail.com
}

\begin{abstract}
ABSTRAK
Abstract: This study aims to determine the increase in motor activity in learning through rhythmic gymnastics. This study included classroom action research in two cycles. Each cycle is carried out in the form of a cycle study process consisting of four stages, namely planning, implementation, observation, and reflection. The target of the study was students of class VI-A Samarinda Ilir 020 Public Elementary School. Data obtained in the form of formative test results, performance tests, and observation sheets in learning activities. Based on the results of the analysis there is an increase in student activity from the first cycle (70\%) and secondly (80\%). In addition, based on observations of students during the Rhythmic Gymnastics practice learning moves actively both when getting assignments from the teacher or their own initiative. In teaching activities the teacher showed an increase in the first cycle (95\%) and the second cycle (100\%). This shows that the teacher has taught according to the learning scenario.

Abstrak: Penelitian ini bertujuan untuk mengetahui peningkatan aktivitas motorik dalam pembelajaran melalui senam ritmik. Penelitian ini termasuk penelitian tindakan kelas sebanyak dua siklus. Setiap siklus dilaksanakan dalam wujud proses pengkajian berdaur yang terdiri atas empat tahap, yakni perencanaan, pelaksanaan, observasi, dan refleksi. Sasaran penelitian adalah siswa kelas VI-A Sekolah Dasar Negeri 020 Samarinda Ilir. Data yang diperoleh berupa hasil tes formatif, performance test, dan lembar observasi dalam kegiatan pembelajaran. Berdasarkan hasil analisis terdapat peningkatan aktivitas siswa dari siklus pertama (70\%) dan kedua yakni (80\%). Selain itu, berdasarkan observasi siswa selama mengikuti pembelajaran praktik Senam Ritmik bergerak aktif baik saat mendapat tugas dari guru ataupun inisiatif sendiri. Pada aktivitas mengajar guru menunjukkan peningkatan pada siklus pertama (95\%) dan siklus kedua (100\%). Hal ini menunjukkan bahwa guru telah mengajar sesuai dengan skenario pembelajaran.
\end{abstract}

Sarana prasarana merupakan salah satu bagian yang strategis dalam pencapaian tujuan pembelajaran (Mahnun, 2012) (Triyanto, dkk. 2013). Dengan kata lain, lengkap dan tidak lengkapnya sarana prasarana pembelajaran turut memengaruhi maksimal dan tidak maksimalnya ketercapaian tujuan pembelajaran (Puspitasari, 2016). Sarana yang lengkap bisa memudahkan guru untuk mengejar target-target tertentu yang menjadi tujuan pembelajaranya (Jatmika, 2005). Hal ini terjadi pada pembelajaran praktik senam ritmik pada siswa kelas VI-A semester 12 Sekolah Dasar Negeri 020 Jalan Damai Kelurahan Sidodamai Samarinda Ilir Tahun Ajaran 2014/2015, Kondisi nyata di sekolah, media praktik senam ritmik hanya tersedia dua buah, satu untuk putri dan satu untuk putra. Berdasarkan fakta tersebut, proses pembelajaran praktik senam ritmik menjadi tidak efektif dan mengakibatkan tidak tercapainya target kurikulum. Berdasarkan permasalahan tersebut, perlu sebuah pemecahan masalah yang sederhana dan bisa dilakukan oleh guru. Salah satu solusi yang memungkinkan adalah perlu adanya sebuah media alternatif untuk praktik senam ritmik. Media alternatif tersebut akan digunakan saat pembelajaran senam ritmik tanpa menggunakan alat.

Masa usia dini ini merupakan masa perkembangan anak yang pendek, tetapi merupakan masa penting bagi kehidupannya. Oleh karena itu, pada masa ini seluruh potensi yang dimiliki anak perlu didorong sehingga akan berkembang secara optimal (Asmawati, dkk. 2014). Karakteristik perkembangan anak pada SD biasanya pertumbuhan fisiknya telah mencapai kematangan, mereka telah mampu mengontrol tubuh dan keseimbangannya (Rahman, 2009). Selain itu, perkembangan anak dari sisi sosial, terutama anak yang berada pada usia kelas awal SD, mereka dapat menunjukkan keakuannya tentang jenis kelaminnya, mulai 
berkompetisi dengan teman sebaya, mempunyai sahabat, mampu berbagi, dan mandiri (Mayar, 2013) (Aisyah, dkk. 2014). Pentingnya perkembangan psikomotorik dalam pembelajaran yang dipaparkan oleh Hurlock (1990) sebagai berikut. Pertama, melalui ketrampilan motorik, anak dapat menghibur dirinya dan memperoleh perasaan senang. Kedua, dengan keterampilan motorik anak dapat bergerak dari satu tempat ketempat yang lain, dan dapat berbuat sendiri untuk dirinya sendiri. Kondisi ini akan menunjang perkembangan rasa percaya diri. Ketiga, melalui peningkatan potensi perkembangan psikomotorik anak dapat menyesuaikan dangan lingkungan sekolah. Keempat, melalui peningkatan potensi perkembangan psikomotorik yang normal memungkinkan anak dapat bermain dan bergaul dengan teman sebayanya. Kelima, peningkatan potensi perkembangan psikomotorik sangat penting bagi perkembangan self concept (kepribadian anak).

Adapun dalam perkembangannya terdapat tahapan-tahapan dalam perkembangan psikomotorik, yaitu (1) tahap kognitif Tahap ini ditandai dengan adanya gerakan gerakan yang kaku dan lambat. (2) Tahap Asosiatif, pada tahap ini seorang anak ataupun siswa membutuhkan waktu yang lebih pendek untuk memikirkan tentang gerakanya. (3) Tahap otonomi Pada tahap ini seorang siswa telah mencapai tingkat otonomi yang tinggi, proses belajarnya sudah hampir lengkap meskipun dia masih dapat memperbaiki gerakan-gerakan yang dipelajarinya (Piaget, 2010). Tahap ini disebut tahap otonomi karena siswa sudah tidak memerlukan kehadiran instruktur untuk melakukan gerakan gerakan (Trianingsih, 2016). Teknik yang bisa digunakan untuk mengembangkan potensi psikomotorik pada peserta didik di antaranya adalah model permainan atau out bond (Hartadji, 2017; Harsanti, 2018). Model meniru, model kelompok belajar dan bermain stimulasi untuk meningkatkan potensi psikomotorik dapat dilakukan di antaranya dengan cara diberikan dasar dasar keterampilan untuk menulis dan menggambar, keterampilan berolahraga atau menggunakan alat olahraga, gerakan gerakan perrnainan, seperti melompat memanjat dan berlari, dan baris-berbaris secara sederhana.

Disebut juga senam irama karena seluruh gerakannya harus sesuai dengan irama yang mengiringinya (Suharjana, 2010). Senam ritmik dapat dilakukan tanpa alat maupun dengan alat yang dipegang, seperti bola, tali, tongkat, sampai, dan gada. Senam ritmik menuntut kepala, lengan, togok, dan kaki bergerak selaras dengan irama yang mengiringi (Suharjana, 2010). Tinggi rendahnya tingkat kesulitan gerakan merupakan kontribusi untuk mendapatkan nilai yang paling besar. Adapun pada aktivitas ritmik ada tiga hal yang harus diperhatikan, yakni fleksibilitas, kontinuitas, dan ketepatan dengan irama. Gerakan-gerakan dalam senam irama bertujuan untuk melemaskan otot-otot tubuh, memperluas gerak persendian, menghilangkan cedera otot, meningkatkan kesehatan, dan kebugaran jasmani. Dalam senam ritmik, terdapat gerakan dasar yang harus dikuasai (baik dengan alat maupun tanpa alat), Gerakan dasar tersebut meliputi (1) langkah, atau berpindahnya salah satu kaki belakang ke depan kaki yang lainnya dengan berbagai variasi (langkah biasa, keseimbangan, ke depan); (2) loncat, adalah gerakan melangkah disertai tolakan kaki sehingga ada scat badan melayang di udara, mendarat dengan salah satu kaki disusul dengan kaki yang lainnya (Loncat biasa, kuda, pantul); (3) sikap Badan ketika senam berhenti baik untuk pergantian gerak kombinasi maupun gerak akhir dengan selesainya suatu irama (Sikap berdiri, duduk, berbaring, tidur terlentang); (4) step, adalah melangkah dengan tanpa mengubah posisi kaki, artinya kaki depan setelah mendarat kakinya tetap di depan dan mendaratnya dengan satu kaki disusul kaki yang lainnya; (5) ayunan lengan satu lengan maupun dua lengan dapat digerakkan dengan berbagai variasi, misalnya ke samping kananl kiri, ke depan/belakang, melingkar ke kanan ke kiri, melingkar ke depan/ belakang; (6) pilinan, adalah memutar badan ke arah kanan atau kiri dengan bertumpu pada satu kaki; (7) liukan, adalah gerakan menggeliat seakan bergelombang dengan gerakan pinggul lebih aktif. Variasi atau macam gerakan bisa meliuk ke kanan atau ke kiri; (9) gerakan memutar badan adalah berpindahnya salah satu kaki diikuti oleh kaki yang lainnya ke arah melingkar ke kiri atau ke kanan. Gerakan memutar badan bisa 180. atau langsung 360.

Dalam aplikasinya, latihan gerakan senam ritmik tanpa menggunakan alat dapat dilakukan dengan gerakan-gerakan sebagai berikut. Pertama, ayunan tangan, gerakan tangan atau lengan yang paling mudah dilakukan adalah ke samping kanan atau kiri untuk dikombinasikan dengan gerakan lainnya. Kedua, latihan gerakan ayunan tangan ke kanan dan ke kiri disertai langkah kaki. Ketiga, putaran badan disertai liukan. Keempat, gerakan loncatan, Hal-hal yang perlu diperhatikan dalam melakukan gerakan loncatan adalah tolakan kaki, tumpuan, dan gerakan dengan kaki meruncing. Latihan loncatan ini bisa bervariasi misalnya ke belakang, ke samping kanan atau ke kiri, atau dikombinasikan dengan gerakan-gerakan yang lainnya, seperti melangkah, memutar, step, dan seterusnya. Kelima, penyesuaian gerak dengan irama, musik atau irama yang lazim digunakan untuk mengiringi senam ritmik adalah musik balet. Untuk menyesuaikan gerakan senam yang sudah dirancang sedemikian rupa bisa sesuai dan berakhir dengan maka perlu memperhatikan intro musik, musik inti, dan musik penutup. 


\section{METODE}

Penelitian menggunakan metode penelitian tindakan kelas dengan waktu pelaksanaan mulai bulan Maret hingga Mei 2015. Penentuan pelaksanan penelitian mengacu pada kalender pendidikan SDN 020 dan mempertimbangkan siklus yang memerlukan proses pembelajaran yang efektif dan efisien. Subjek penelitian ini adalah peneliti sebagai Kepala Sekolah Dasar Negeri 020 Samarinda Ilir, subjek dari penelitian ini adalah siswa kelas VI.A semester 12 Sekolah Dasar Negeri 020 Jalan Damai Kelurahan Sidodamai Samarinda Il Tahun Ajaran 2014/2015 Samarinda Ilir dengan jumlah siswa putri 15 orang dan putra 16 orang.

Sebelum melaksanakan penelitian dilakukan terlebih dahulu tahap perencanaan. Tahap ini bertujuan untuk mengidentifikasi masalah dan menyiapkan perangkat penelitian (RPP dan lembar observasi). Setelah itu dilaksanakan tahap penelitian yang terdiri dari dua siklus mengadopsi rancangan pelaksanaan penelitian tindakan kelas oleh Arikunto (2006) yang dapat dilihat pada gambar 1.

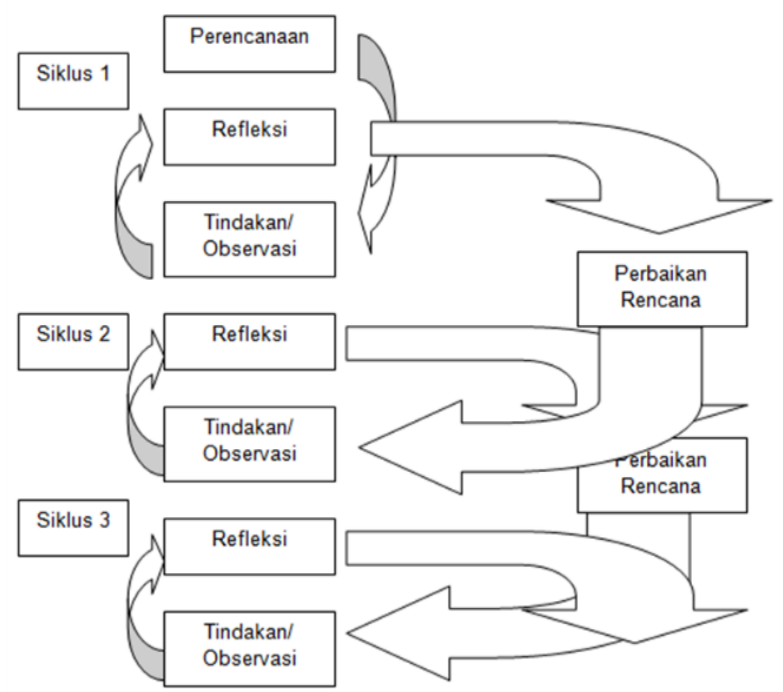

Gambar 1. Bagan Rancangan Pelaksanaan PTK Model Spiral (Arikunto, 2006)

Berdasarkan rancangan tersebut, setiap siklus memiliki empat tahapan utama yakni perencanaan, pelaksanaan, observasi, dan refleksi. Adapun kegiatan-kegiatan yang dilaksanakan setiap tahapan siklus dapat dilihat pada tabel 1.

\section{Tabel 1. Uraian Kegiatan Setiap Tahapan Siklus}

\begin{tabular}{|c|c|c|}
\hline Tahapan & Siklus I & Siklus II \\
\hline Perencanaan & $\begin{array}{ll}\text { 1. } & \text { Analisis kurikulum } \\
\text { 2. } & \text { Membuat RPP } \\
\text { 3. } & \text { Menyusun Instrumen } \\
\text { 4. } & \text { MEnyiapkan alat bantu pembelajaran } \\
\text { 5. } & \text { Menyusun evaluasi } \\
\text { 6. } & \text { Menyiapkan praktik senam ritmik }\end{array}$ & $\begin{array}{l}\text { Tindakakan dikaitkan dengan hasil yang dicapai pada siklus } \\
\text { pertama sebagai upaya perbaikan. Sebagai tambahan disusun } \\
\text { juga lembar kegiatan siswa dan tes formatif untuk } \\
\text { mengumpulkan data hasil kegiatan siswa. }\end{array}$ \\
\hline Observasi & $\begin{array}{l}\text { Pengamatan terhadap penerapan metode pembelajaran } \\
\text { langsung pendidikan jasmani metode pendekatan bermain } \\
\text { dengan alat modifikasi yang diterapkan terhadap proses } \\
\text { pembelajaran penjas. }\end{array}$ & $\begin{array}{l}\text { Hasil pengamatan yang dilakukan dengan menggunakan } \\
\text { lembar kerja pengamatan melihat ketika siswa mengikuti } \\
\text { proses pembelajaran. }\end{array}$ \\
\hline
\end{tabular}


Setelah rancangan kegiatan ditetapkan, langkah selanjutnya adalah pelaksanaan pengumpulan data. Teknik pengumpulan data yang digunakan dalam penelitian adalah; Pengamatan, kegiatan anak melakukan percobaan yang dijadikan sampel penelitian (Moleong, 2004). Dalam pelaksanaannya, teknik digunakan secara proporsional sesuai dengan jenis data yang diperlukan peneliti. Untuk mengumpulkan data penelitian, dilakukan dengan cara menentukan sumber data terlebih dahulu, kemudian jenis data, teknik pengumpulan data, dan instrumen yang digunakan. Teknik pengumpulan data secara lengkap dapat dilihat pada tabel 2.

Tabel 2. Sumber, Jenis, dan Teknik Pengumpulan Data

\begin{tabular}{cll}
\hline Sumber Data & \multicolumn{1}{c}{ Jenis Data } & \multicolumn{1}{c}{ Teknik Pengumpulan Data } \\
\hline Siswa & Aktivitas siswa dalam belajar Senam Ritmik & Observasi \\
Siswa & Hasil Belajar Siswa & $\begin{array}{l}\text { Tes siswa melakukan awalan, cara } \\
\text { melakukan senam ritmik, dan sikap akhir }\end{array}$ \\
Siswa & $\begin{array}{l}\text { Respon Siswa (tingkat kepuasan terhadap } \\
\text { proses pembelajaran) }\end{array}$ & Penyebaran angket \\
Guru & Aktivitas mengajar guru & Observasi \\
\hline
\end{tabular}

Analisis data yang digunakan bersifat kualitatif yaitu data berdasarkan mutu keberhasilan siswa dalam mengikuti proses pembelajaran. Hasil belajar juga dapat dilihat dan tiga aspek, yaitu secara kuantitatif, institusional, dan kualitatif. Aspek kuantitatif menekankan pada pengisian dan pengembangan kemampuan kognitif dengan fakta-fakta yang berarti. Aspek insitusional atau kelembagaan menekankan pada ukuran seberapa baik perolehan belajar siswa yang dinyatakan dalam angka-angka. Aspek kualitatif menekankan pada seberapa baik pemahaman dan penafsiran siswa terhadap lingkungan di sekitarnya. Sehingga dapat memecahkan masalah yang dihadapinya dalam kehidupan sehari-hari. Proses analisis data dimulai dengan menelah seluruh data yang tersedia dari bersumber, yaitu hasil pengamatan, daftar nilai tiap siklus.

\section{HASIL DAN PEMBAHASAN}

\section{Penjelasan setiap Siklus}

Pada pra siklus pertama, hasil tes praktik Senam Ritmik menunjukkan hanya enam siswa yang mampu menuntaskan pembelajaran (19.35\%). Pada siklus pertama, persentase ketuntasan meningkat menjadi 19 orang (61.3\%). Pada siklus II ketuntasan belajar mencapai 31 siswa (100\%). Dari hasil tersebut dapat dilihat bahwa peningkatan persentase ketuntasan belajar meningkat setiap siklus.

\section{Aktivitas Siswa dan Guru Dalam Belajar Praktik Senam Ritmik}

Berdasarkan hasil observasi, aktivitas siswa pada dua siklus penelitian proses pembelajaran praktik Senam Ritmik menunjukan adanya peningkatan aktivitas siswa dari siklus pertama sampai siklus kedua. Peningkatan tersebut sebesar $70 \%$ pada siklus pertama dan $80 \%$ pada siklus kedua. Berdasarkan hasil tersebut, terdapat peningkatan sebesar $10 \%$ setelah ada perbaikan pada siklus kedua, sehingga rata-rata keaktifan siswa selama dua siklus adalah 75\%. Mengacu pada indikator keaktifan siswa, kisaran angka 75\% memiliki kriteria aktif. Dengan kata lain, selama mengikuti pembelajaran praktik Senam Ritmik siswa bergerak aktif baik saat mendapat tugas dari guru ataupun inisiatif sendiri.

Pada hasil observasi guru yang dilakukan oleh rekan guru aktivitas mengajar guru pada siklus pertama mencapai tingkat pencapaian 95\%, sedangkan pada siklus kedua mencapai 100\%. Ini berarti ada kenaikan aktivitas guru sebesar 5\%, sehingga ratarata aktivitas guru pada dua siklus mencapai 97,5\%. Mengacu pada indikator aktivitas guru, angka 97,5\% termasuk kriteria sangat aktif. Hal tersebut menandakan bahwa guru dalam mengajar telah sesuai dengan skenario pembelajaran.

\section{Hasil Observasi Kegiatan Siswa}

Setelah melakukan dan menyelesaikan siklus I, pengamatan dilakukan pada kegiatan belajar siswa. Hasil pengamatan pertama yang perlu ditingkatkan adalah praktik gerak ritmik sederhana dengan gerakan membungkuk, menekuk, meliuk, jalan dan lompat secara berpasangan dan beregu. Ditambah dengan nilai kerja sama, disiplin, dan estetika dengan menggunakan alat bantu bola, tali, tongkat, dan gada. Perhatian lebih juga perlu diberikan terutama pada siswa puttri dalam teknik menekuk, meliuk, jalan, dan lompat. Selanjutnya, bagi guru pengajar perlu ditingkatkan dengan melihat kembali RPP pada aktivitas mengajar praktik senam 
ritmik. Pada siklus kedua pengamatan kembali dilakukan berdasarkan refleksi yang dilakukan pada siklus pertama. Hasil menunjukkan bahwa kemampuan praktik gerak ritmik siswa meningkat. Begitu pula dengan aktivitas mengajar guru yang juga meningkat sesuai dengan RPP.

\section{Respon Siswa terhadap Proses Pembelajaran}

Berdasarkan angket respon, yang disebarkan kepada siswa setelah selesai pelaksanaan pembelajaran siklus kedua, dapat dinyatakan bahwa pada umumnya siswa kelas VI bersikap positif terhadap proses pembelajaran raktik Senam Ritmik. Persentase siswa yang merasa senang dengan pembelajaran Praktik Senam Ritmik sebesar 85\%, sedangkan yang menyatakan biasa-biasa saja 10\%, dan merasa tidak senang 5\%. Kondisi ini berarti bahwa sebagian besar siswa menikmati proses pembelajaran Praktik Senam Ritmik ditanggapi positif oleh siswa, dengan pernyataan bahwa sebanyak 85\% menyatakan mempraktikkan Senam Ritmik memudahkan dalam proses pembelajaran mempraktikkan Senam Ritmik, sebanyak 10\% menyatakan biasa-biasa saja, dan hanya sebesar 5\% yang merasa sulit.

Terkait dengan tugas selama proses pembelajaran berlangsung tanggapanya siswa sebagian besar positif, yaitu $80 \%$ menyatakan mudah, $10 \%$ menyatakan biasa-biasa saja, dan $10 \%$ menyatakan susah. Mengacu pada indikator respon siswa, maka rata-rata tingkat respon siswa 85\%, mempunyai kriteria sangat puas. Kriteria ini menggambarkan bahwa siswa merasa tertarik dan sangat menikmati pembelajaran. Hasil ini didukung oleh penelitian serupa, seperti penelitian oleh Citrasari (2014), keterampilan senam ritmik anak kelompok B1 TK Negeri Pembina Sukoharjo dapat ditingkatkan melalui media Simpai. Hal tersebut dapat dilihat dari peningkatan yang dialami pada penelitian yang dilakukan peneliti, dari pra siklus, siklus I, dan siklus II. Pada penelitian lain menyatakan bahwa melalui pendekatan pembelajaran bermain tali pada materi senam lantai meroda dapat meningkatkan keterampilan senam meroda siswa kelas VIIIA MTs Ma'arif NU Kemiri (Wuryantoro \& Muktiani 2011). Selain itu, penelitian oleh Hanief (2016), menyatakan bahwa media alat bantu tali lebih baik pengaruhnya terhadap peningkatan keterampilan back handspring dibanding dengan bantuan teman.

\section{SIMPULAN}

Berdasarkan hasil evaluasi dan observasi pembelajaran senam ritmik aktivitas siswa selama mengikuti proses pembelajaran terdapat peningkatan ketuntasan belajar dari pra siklus (19.35\%), siklus pertama (61.3\%), dan siklus kedua (100\%). Peningkatan juga terjadi pada aktivitas siswa dalam belajar praktik Senam Ritmik yaitu $70 \%$ (siklus I) menjadi $80 \%$ (siklus II), sedangkan aktivitas mengajar guru meningkat dari 95\% (siklus I) menjadi 100\% (siklus II). Respon positif juga ditunjukkan oleh siswa terhadap proses pembelajaran yang menunjukkan sebagian besar siswa merasa tertarik dan menikmati pembelajaran. Adapun upaya untuk penelitian selanjutnya adalah dengan meningkatkan kualitas pembelajaran yaitu dengan menggunakan strategi mengajar yang tepat sehingga dapat menciptakan pembelajaran yang menarik bagi siswa.

\section{DAFTAR RUJUKAN}

Aisyah, S., Amini, M., Chandrawati, T., \& Novita, D. (2014). Perkembangan dan Konsep Dasar Pengembangan Anak Usia Dini. Jakarta: Rineka Cipta.

Arikunto, S. (2006). Prosedur Penelitian Suatu Pendekatan Praktik. Jakarta: Rineka Cipta.

Citrasari, Y. (2014). Upaya Meningkatkan Keterampilan Senam Ritmik melalui Media Sampai pada Anak Kelompok B1 di TK Negeri Pembina Sukoharjo Tahun Ajaran 2013/2014. Disertasi tidak diterbitkan. Universitas Muhammadiyah Surakarta, Surakarta.

Hanief, Y. N. (2016). Perbedaan Pengaruh Pengunaan Alat Bantu Tali dan Bantuan Teman terhadap Peningkatan Keterampilan Back Handspring. In Prosiding Seminar Nasional Pendidikan Jasmani Pascasarjana UM (pp. 192-202).

Harsanti, A. G. (2018). Pengembangan Perangkat Pembelajaran dengan Menggunakan Outbond untuk Peningkatan Perilaku Sosial Siswa Kelas IV SDN 01 Tawangrejo. Buana Pendidikan: Jurnal Fakultas Keguruan dan Ilmu Pendidikan, 14(25), 21-29.

Hartadji, R. H. (2017). Model Permainan Aktivitas Luar Kelas untuk Mengembangkan Ranah Kognitif, Afektif, dan Psikomotorik Siswa SMA. Journal of SPORT, 1(1), 148-174.

Jatmika, H. M. (2005). Pemanfaatan Media Visual dalam Menunjang Pembelajaran Pendidikan Jasmani di Sekolah Dasar. Jurnal Pendidikan Jasmani Indonesia, 3(1).

Mayar, F. (2013). Perkembangan Sosial Anak Usia Dini sebagai Bibit untuk Masa Depan Bangsa. Al-Ta lim Journal, 20(3), $459-464$.

Mahnun, N. (2012). Media Pembelajaran (Kajian terhadap Langkah-langkah Pemilihan Media dan Implementasinya dalam Pembelajaran). An-Nida', 37(1), 27-34.

Moleong, L. J. (2004). Metodologi Penelitian Kualitatif. Bandung: Remaja Rosdakarya. 
Piaget, J. \& Inhelder, B. (2010). Psikologi Anak: The Psychology of the Child. Jakarta: Pustaka Pelajar.

Puspitasari, W. D. (2016). Pengaruh Sarana Belajar terhadap Prestasi Belajar Ilmu Pengetahuan Sosial di Sekolah Dasar. Jurnal Cakrawala Pendas, 2(2).

Rahman, U. (2009). Karakteristik Perkembangan Anak Usia Dini. Lentera Pendidikan: Jurnal Ilmu Tarbiyah dan Keguruan, $12(1), 46-57$.

Suharjana, F. (2010). Aktivitas Ritmik dalam Pendidikan Jasmani di Sekolah Dasar. Jurnal Pendidikan Jasmani Indonesia, 7(1), 16.

Trianingsih, R. (2016). Pengantar Praktik Mendidik Anak Usia Sekolah Dasar. Al Ibtida: Jurnal Pendidikan Guru MI, 3(2), $197-211$.

Triyanto, E., Anitah, S., \& Suryani, N. (2013). Peran Kepemimpinan Kepala Sekolah dalam Pemanfaatan Media Pembelajaran sebagai Upaya Peningkatan Kualitas Proses Pembelajaran. Teknologi Pendidikan, 1(2), 226 - 238.

Wuryantoro, K., \& Muktiani, N. R. (2011). Meningkatkan Keterampilan Senam Meroda melalui Permainan Tali pada Siswa Kelas VIII-A MTS Ma’arif NU. Jurnal Pendidikan Jasmani Indonesia, 8(2). 